\title{
The effect of ant-plant (Hydnophytum formicarum) ethanol extract on collagen fibers for wound healing after tooth extraction in the guinea pig (Cavia cobaya)
}

\author{
Siti Velanita ${ }^{*}$, Efa Ismardianita ${ }^{1}$, Andries Pascawinata ${ }^{1}$ \\ 'Department of Oral Surgery, Faculty of Dentistry Baiturrahmah University, Indonesia
}

\begin{abstract}
Introduction: Tooth extraction causes tissue damage around the socket. Wound healing is essential for repairing damaged tissues. One of the medicinal plants often used is ant-plant (Hydnophytum formicarum), which contains flavonoids, triterpenoids, saponins and tannins. This research was aimed to determine the effect of ant-plant ethanol extract on the density of collagen fibers for wound healing after tooth extraction in the guinea pig (Cavia cobaya). Methods: The type of research was true experimental with a post-test only control group design. The study used 48 male guinea pig divided into 4 groups. Experimental groups received lower left incisor extraction, the control group was orally administered with $0.5 \%$ CMC, and the treatment group was administered with ant-plant extract dissolved with $0.5 \%$ CMC with dose of $4.65 \mathrm{mg}, 6.2 \mathrm{mg}$, and $9.3 \mathrm{mg}$ respectively; each guinea pig was given $3 \mathrm{cc}$ of the extract 3 times a day until the termination day. On day $3,7,14$, and 21 respectively, the guinea pigs were terminated and to make the histological preparations. The difference in collagen fibers density of the two observation groups was tested with one-way ANOVA, and the LSD test to analyse the significance between groups. Results: Application of ant-nest ethanol extract showed significant effects on the density of collagen fibers in the wound healing process after tooth extraction. Results of the one-way ANOVA test showed significant value on all treatment groups $(p<0.05)$. There were also found significant differences between the control group and the treatment group $(\mathrm{p}<0.05)$. Conclusion: Ant-plant (Hydnophytum formicarum) ethanol extract increase the collagen fibers density on the wound healing after tooth extraction with the effective dose of $4.65 \mathrm{mg}$.
\end{abstract}

Keywords: Ant-plant, Hydnophytum formicarum, wound healing, collagen, guinea pig, Cavia cobaya.

p-ISSN: 1979-0201; e-ISSN: 2549-6212; Available from: http://jurnal.unpad.ac.id/pid/article/view/19328

DOI: 10.24198/pjd.vol31no1.19328

Submission: Nov 15, 2018; Accepted: Nov 7, 2019; Published online: Nov 30, 2019

\section{INTRODUCTION}

Tooth extraction is generally performed when a tooth cannot be restored or maintained. Tooth extraction causes tissue damage around the socket. In this condition, microorganisms will easily invade the wound area, which can inhibit wound healing. Invasion of bacteria needs to be inhibited; thus, the wound healing must be performed immediately. Wound healing after 
tooth extraction generally runs well but often constrained with problems and complications which require medications. ${ }^{1}$

Formation of collagen fibers in wound healing is essential to support the strength of tissue in the area of injury. Collagen is a fiber-shaped protein and a significant part of connective tissue required for wound healing, scar tissue formation, and bone matrix formation. . $^{2,3,4}$

Collagen is a critical component of the wound healing phase. Collagen fragments release leukocytic collagenases to recruit fibroblasts to the wound area. Ten hours after the wound, collagen synthesis will increase. At the 5th - 7th day, the collagen synthesis reaches its peak then decreasing. ${ }^{3,4}$

One of the medicinal plants used for a long time by people in the Mentawai Islands of West Sumatra is an ant-nest tuber (Hydnophytum sp). ${ }^{5}$ Analysis of Hydnopythum formicarum chemical compositions discovered flavonoids, saponins, tannins, tocopherols, and polysaccharides. ${ }^{6,7}$

Flavonoids act as antibacterial by forming complex compounds towards the extracellular proteins and interfering the integrity of bacterial cell membranes. ${ }^{8,9}$ Saponins are a class of steroids that can stop bleeding and treat wounds. Saponins are substances that can accelerate the coagulation of red blood cells. Tanin is an active compound of secondary metabolites, has properties like astringent, antibacterial, and antioxidants. ${ }^{10,11}$

The formation of collagen fibers in the process of wound healing after tooth extraction is critical to support the strength of tissue at the site of the wound; thus, this research was aimed to determine the effect of ant-plant ethanol extract on the density of collagen fibers for wound healing after tooth extraction in the guinea pig (Cavia cobaya).

\section{METHODS}

This study was an experimental research with post-test only control group design. Materials used were ethanol extract of $70 \%$ ant-plant (Hydnopythum formicarum), 0.5\% CMC, ketamine, xylazine, $10 \%$ formalin buffer, xylol, paraffin, and hematoxylin-eosin. The plants was identified in the Herbarium Laboratory of Andalas University. The ant-plant tested was included to the family of Rubiaceae with the species of Hydnophytum formicarum Jack., with identification registration number 037/K-ID/YOU/II/2016.

The extract preparation and the phytochemical test was conducted in the Chemistry Laboratory of Universitas Padjadjaran, and prior knowledge of this plant's chemical composition was flavonoid, phenol, triterpenoid, and tannin. Tooth extraction was carried out at Unit IV Integrated Research Laboratory of Gadjah Mada University. Histologic colouration and observation was performed in the Anatomy Pathology Laboratory of the Faculty of Medicine Gadjah Mada University. The study began from April to July 2016. The study has been approved by the Research Ethics Committee of the Faculty of Medicine of Andalas University with the registration number of 073/KEP/FK/2016.

The ant-plant tuber extract was obtained by peeling the ant-plant, then thinly sliced $(3-5 \mathrm{~mm}$ slices), dried in the oven with the temperature of $500^{\circ} \mathrm{C}$ to dried the tuber dry thus easy to be broken, and mixed until the coarse powder escaped without any help of a sieve. ${ }^{12} \mathrm{~A}$ total of $1000 \mathrm{~g}$ of ant-plant tuber dried powder was then immersed with $70 \%$ ethanol with the ratio of 1:5. The maceration was performed by shaking the mixture in the first 6 hours, followed by 18 hours of incubation. The maceration was carried out several times until the filtrate colour changed. The obtained filtrate was then evaporated with a rotary evaporator at the temperature of $500^{\circ} \mathrm{C}$, then put into the oven until all the water evaporated and the extract dried, to get a thickened extract with fixed weight (not dripping).

The previous study conducted by Suryajaya ${ }^{13}$ determined that the dose of ant-plant extract given to humans in powder form was 1500-3000 $\mathrm{mg} /$ day $(1-2$ capsules @ $500 \mathrm{mg}$, three times daily). The human dose conversed to the scale of $70 \mathrm{~kg}$ for the guinea pig weighed 400 gram, which was 0.031 thus the dosage used in this research were dose I: $4.65 \mathrm{mg} / 400 \mathrm{~g}$ bw/day, dose II: 6.2 $\mathrm{mg} / 00 \mathrm{~g}$ bw/day, and dose III: $9.3 \mathrm{mg} / 400 \mathrm{~g} \mathrm{bw} /$ day. Animal care of experimental has been approved by the Ethical Committee of the Faculty of Dentistry Baiturrahmah University.

The population in this study were male guinea pigs. Inclusion criteria were male guinea pig, weighing 250 - 400 grams, aged 6 - 8 weeks. 
Exclusion criteria were the guinea pig that died during treatment. The sample size was determined by the formula of Federer: $(t-1)(n-1) \geq 15$. There were four treatment groups (control, dose I, dose II, and dose III) with observation time in day 3 , day 7 , day 14 , and day 21 , the sample size was 48 guinea pigs, each group consisted of 3 guinea pig. Independent variables was ant-plant tuber extract and dependent variable was the collagen fibers.

The mantle was adapted for one week, then anesthetised IM with ketamine $(0.1 \mathrm{ml})$ and xylazine $(0.1 \mathrm{ml})$. After the guinea pig in the control group was removed, $0.5 \%$ CMC was administered to the treatment group with $3.3 \mathrm{ml}$ of dose I, II, and III orally using gastric sick $3 x$ daily, until the termination day. The socket tissue was then taken and embalmed with $10 \%$ formalin buffer; then the tissue processing was performed for making histological preparations with HE staining.

Observation of histologic preparations was conducted with the help of a microscope. First, the socket area was determined under 40x magnification; then the observed area was determined under 400x magnification until the one-third apical socket was seen. The results of the preparations in the control group were used as indicators to determine the increase in the formation of collagen fibers. Increase of the collagen fibers formation scored with criteria that have been established as follows: $0=$ No collagen fibers found in the wound area; $+1=$ Low density of collagen fibers in the wound area (less than $10 \%$ per field of view) $+2=$ Moderate density of collagen fibers in moderate wound area $(10 \mathrm{~s} / \mathrm{d}$ $50 \%$ per field of view) $;+3=$ High density of collagen fibers in the wound area (50 to $90 \%$ per field of view); and $+4=$ Very high density of collagen fibers in the wound area (90 to $100 \%$ per field of view).

\section{RESULTS}

Results of identification from Herbarium Laboratory of Andalas University suggested that the ant-plant species was Hydnophytum formicarum Jack. Based on the phytochemical test results conducted at the Chemical Laboratory of Universitas Padjadjaran, the plant contained the actinic substances of phenol, flavonoids, triterpenoids, and tannins.
The observation results showed that the collagen fibers density on the $3^{\text {rd }}, 7^{\text {th }}, 14^{\text {th }}$, and $21^{\text {st }}$ days showed the highest rate of collagen formation of $4.65 \mathrm{mg}$. The observed area was at four fields of view, which were the apex, medial, cervical, and lateral using a light microscope with 400x magnification.

From the normality test results of all groups at day $3,7,14$, and 21 , the significance value was $p>0.05$ (Table 1), indicated that the data was normally distributed. Based on the homogeneity test results, obtained the significance value $p>0.05$, means the data was distributed

Table 1. Phytochemical test results of Hydnophytum formicarum

\begin{tabular}{llc}
\multicolumn{1}{c}{$\begin{array}{c}\text { Second } \\
\text { metabolict }\end{array}$} & \multicolumn{1}{c}{ Test method } & Test result \\
\hline Phenol & $\mathrm{FeCl}_{3} 5 \%$ & + \\
Flavonoid & $\mathrm{Concentrated} \mathrm{HCl}+\mathrm{Mg}$ & - \\
& $\mathrm{H}_{2} \mathrm{SO}_{4} 2 \mathrm{~N}$ & + \\
& $\mathrm{NaOH} 10 \%$ & + \\
Steroid & $\mathrm{Liebermann-Burchard}$ & - \\
Triterpeneoid & & + \\
Saponin & $\mathrm{HCl}^{2} \mathrm{H}_{2} \mathrm{O}$ & - \\
Tanin & $\mathrm{FeCl}_{3} 1 \%$ & + \\
\hline
\end{tabular}

homogeneously. Furthermore, the parametric test of one-Way ANOVA was conducted to see the effect of collagen formation.

The result of one-way ANOVA test obtained the significance value of $p<0.05$ in all treatment groups, thus can be concluded that there was an influence of oral administration of ethanol extract of ant-plant (Hydnophytum formicarum jack)

Table 2. Result of normality test

\begin{tabular}{llll}
\hline Termination day & $\mathrm{N}$ & Sig & Notes \\
\hline Day 3 & 12 & 0.240 & Normal \\
Day 7 & 12 & 0.241 & Normal \\
Day 14 & 12 & 0.106 & Normal \\
Day 21 & 12 & 0.110 & Normal \\
\hline
\end{tabular}

Table 3. Results of homogenity test with Levene test

\begin{tabular}{lccc}
\hline Termination day & $\mathrm{N}$ & Sig & Notes \\
\hline Day 3 & 12 & 0.330 & Homogenous \\
Day 7 & 12 & 0.106 & Homogenous \\
Day 14 & 12 & 0.132 & Homogenous \\
Day 21 & 12 & 0.114 & Homogenous \\
\hline
\end{tabular}




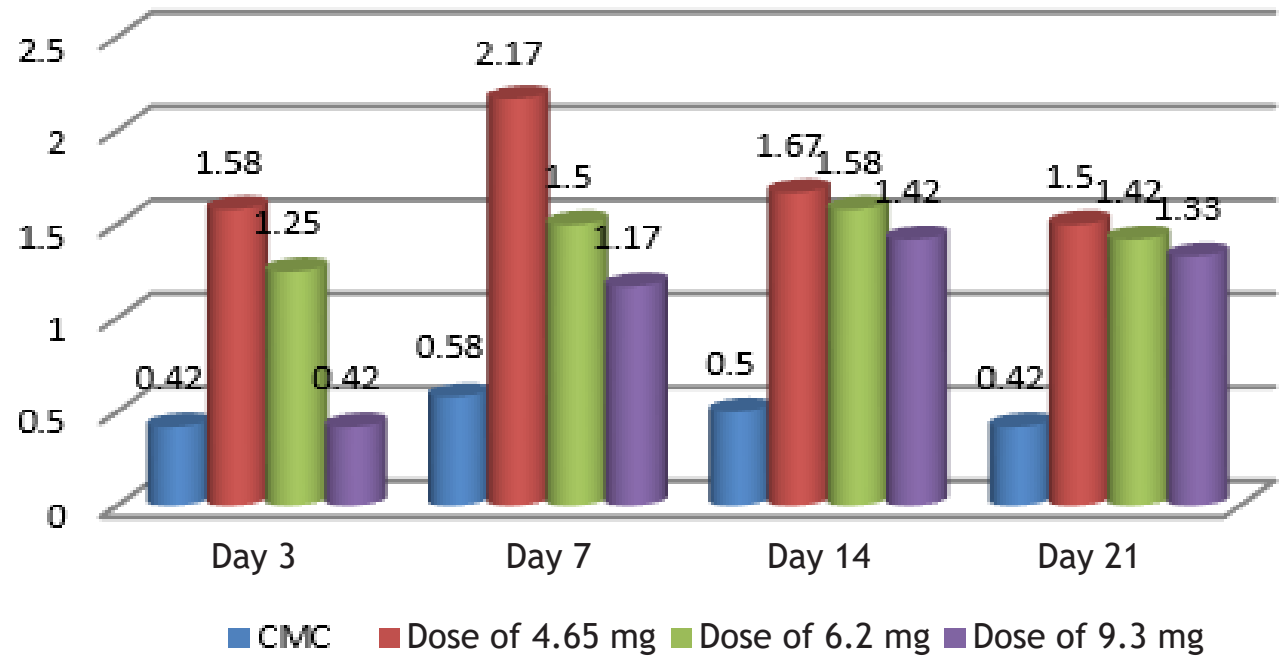

Figure 1. Mean of collagen formation from different treatment in the wound healing after guinea pig tooth extraction

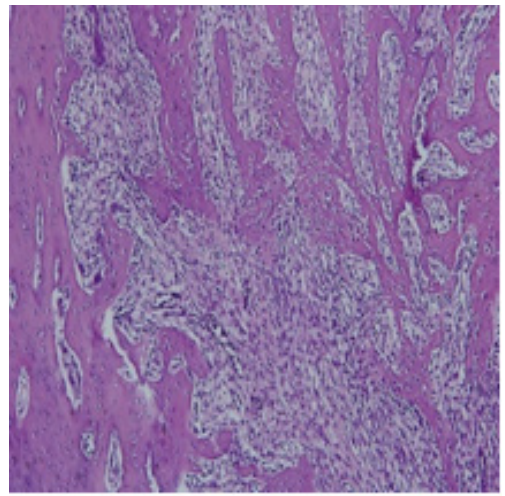

CMC 0.5\%

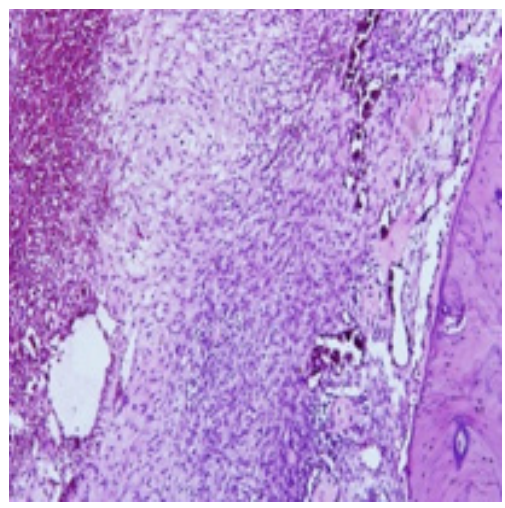

Dose of $6.2 \mathrm{mg}$

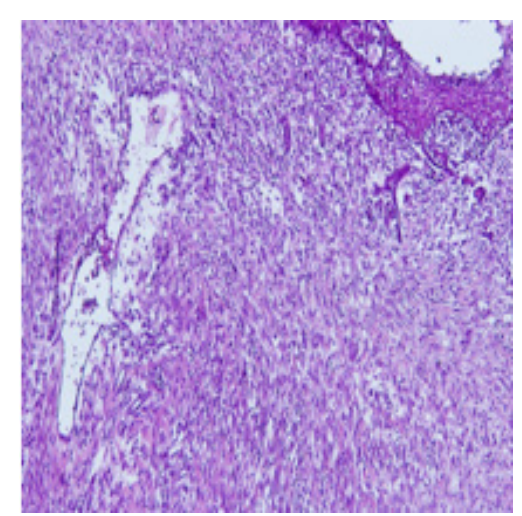

Dose of $4.65 \mathrm{mg}$

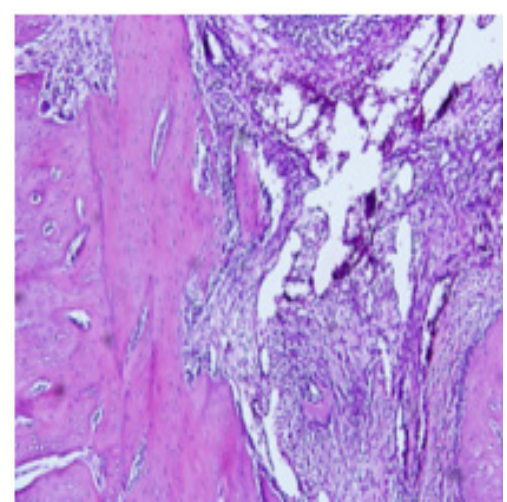

Dose of $9.3 \mathrm{mg}$

Figure 2. An overview of the preparation results the guinea pig socket under $40 x$ magnification

on the collagen formation in the wound healing process post-extraction of guinea pig Cavia cobaya) on day $3,7,14$, and 21 , between the CMC group, the $4.65 \mathrm{mg}$ dose group, the $6.2 \mathrm{mg}$ dose group, and the $9.3 \mathrm{mg}$ dose group.

The LSD test was carried out in advance to determine the comparison of each group at the dose of $4.65 \mathrm{mg}, 6.2 \mathrm{mg}$, and $9.3 \mathrm{mg}$ in the termination day. The result of LSD test between control group and treatment group with the dose of $4.65 \mathrm{mg}, 6.2 \mathrm{mg}$, and $9.3 \mathrm{mg}$ on day $3,7,14$, and 21 showed a difference of colla-gen between control group and treatment group with the dose of $4.65 \mathrm{mg}, 6.2 \mathrm{mg}$, and $9.3 \mathrm{mg}$ on the $3^{\text {rd }}$ day, $7^{\text {th }}$ day, $14^{\text {th }}$ day, and $21^{\text {st }}$ day, thus the hypothesis in this study was accepted. 


\section{DISCUSSION}

On the third day, the collagen fibers in the treatment groups were more increased compared to the control group. Physiologically, the wound healing process begins after tooth extraction, starts from the inflammatory phase. In this phase, the fibroblasts begin to invade the injured area on day three after being stimulated by macrophage products. Activation of macrophages in response to the release of chemoattractants from injured tissue, platelets, neutrophils, lymphocytes, and bacteria, known to help proliferate fibroblasts and increase collagen synthesis. Macrophages can release growth factors such as PDGF (plateletderived growth factor) and TGF-b (transforming growth factor $b$ ) that stimulate cell proliferation in wound healing. PDGF has the ability to activate fibroblasts, and TGF-b is known to induce collagen deposition. ${ }^{14}$

The presence of neutrophils on the thirdday increased osteoclast activity. The initial healing phase in the tooth sockets is the activity of osteoclasts eroding the old socket wall surface, and the healing occurs on the new socket surface. This condition suggested that in the wound healing of the tooth socket, the resorption phase occurs before the regeneration phase. Periodontal ligaments are found to be migrating to the centre of the tooth socket and not attached to the socket wall. The resorption of the buccal and alveolar crest walls causes the socket to extend toward the buccal and alveolar crest and penetrated the tooth socket area. ${ }^{15}$

Collagen fibers appear to be denser at the seventh-day post-extraction in the treatment group than the control group. The thicker collagen fibers begin to dominate the post-extracted tissue of the guinea pig. According to the previous study, on the observation at the end of the first week after tooth extraction, the alveolus appears to be filled with immature connective tissue in the presence of fibroblasts. Fibroblasts are able to proliferate and more actively synthesise matrix components in response to injury. The primary function of fibroblast activation in the injured area is to produce collagen, elastin and proteoglycans. ${ }^{16,17}$

The increase of collagen fibers on the seventh-day was higher than the control group because of the presence of phenol, triterpenoid, tannin, and flavonoid compounds, as the result of the phytochemical test. Flavonoids act as antibacterial by forming complex compounds against extracellular proteins and interfere with the integrity of bacterial cell membranes. The anti-inflammatory activity of flavonoids is carried out by inhibition of cyclooxygenase resulting in limiting the number of inflammatory cells migrating to the injured tissue so that the inflammatory reaction will be shorter and the ability of TGF- $B$ to proliferate cells will not be inhibited. This process leads to a sooner proliferation phase. ${ }^{18}$

Also, flavonoids can reduce the inflammatory process by inhibiting the formation of prostaglandins formed by arachidonic acid and other inflammatory mediators such as serotonin and histamine. Flavonoids have the ability to inhibit the action of arachidonic acid through lipoxygenase and cyclooxygenase pathways followed by inhibition of inflammatory mediators such as thromboxane and leukotriene so that leukocytes can decrease the inflammatory area, thus speeds up the inflammatory process to the proliferation stage and accelerate the healing..$^{19,20}$

Other bioactive compounds detected in the phytochemical test results is tannin that plays a role in wound healing by increasing the regeneration of new tissues. Tannin can heal wounds and reduce scar tissue formation by inhibiting and eliminating the formation of reactive oxygen substances. Tannin also has a complex activity and serves as an astringent that causes shrinkage of the skin or mucosa pores, hardening the mucosa, stopping exudates, stopping mild bleeding, and burning drugs. ${ }^{21}$

The decrease in the density of collagen fibers in the fourteenth-day at the treatment group in the remodelling phase due to the synthesis of collagen type III that was replaced by collagen type I in the form of a ribbon and had stronger flexural strength. The reorganisation of the collagen arrangement and the collagen cross-linking that occurs in the remodelling phase provides new tissue strength and density. ${ }^{22}$

In the tissue maturation stage, the collagen fibers formation are more organised. This phase will proceed to the next healing phase along the time in which the soft callus or hard callus will be formed. The collagen fibers in the formation of new bone, have different diameters and irregular 
arrangements that give the knot or web structure on the bone. The immature bone is referred to as woven. Bone-related glycoproteins such as osteopontin, osteonectin, bone sialoprotein (BSP), osteocalcin, and fibronectin play an essential role in bone formation and mineralisation. Previous research suggested that bone plaiting can be observed 2 to 4 weeks after tooth extraction..$^{16,23}$

The present study suggested that all doses had significant differences compared to the control group; however, at the dose I, there was a more significant increase on the $7^{\text {th }}$ day. Formation of collagen fibers was following the physiological wound healing process, which showed the density peak on day 7 and decreasing on day 14 and 21 . A dose of $4.65 \mathrm{mg}$ was found to be more effective compared with a dose of $6.2 \mathrm{mg}$ and $9.3 \mathrm{mg}$ because the last two dosages were thought to be toxic. At high concentrations, in addition to the presence of active substances in a large number of extracts, there are also other substances, which may also be quite a large amount, and potentially inhibit the active substances. This is often found in the activity of the natural material extract, which is a multi-component mixture. The effects of these components can be synergistic, additive, or even antagonistic. ${ }^{24}$

After observing the effect of ant-plant ethanol extract application on the collagen fibers density in the wound healing process after the tooth extraction of guinea pig (Cavia cobaya), it is necessary to do further research to get a more precise dose for the collagen fiber formation in the wound healing process. This research can become the basis for possible clinical testing in humans.

\section{CONCLUSION}

Oral administration of ant-plant (Hydnophytum formicarum) ethanol extract increase the collagen fibers density on the wound healing after tooth extraction of the guinea pig (Cavia cobaya) with the effective dose of $4.65 \mathrm{mg}$.

\section{REFERENCES}

1. Sugiaman VK. Topical Application of Aloe Vera (Linn.) to Accelerate the Healing Process of the Wound on the Oral Mucosa. Maranatha J Med Health. 2013; 11(1): 70-9.
2. Rosanto YB, Handajani J, Susilowati H. Effect of topical application of banana stem sap gel on the density of collagen fiber in the wound healing process after tooth extraction in the guinea pig. Dentika Dent J. 2012; 17(1): 34-9.

3. Rizka A, Budipramana VS, Fauziah D. Kepadatan kolagen tipe 1 pada luka operasi tikus Wistar yang mengalami anemia karena perdarahan akut. Med J Emergenc. 2013; 2(1): 1-12.

4. Bond JS, Duncan JA, Mason T, Sattar A, Boanas A, O'Kane $S$, et al. Scar redness in hu-mans: how long does it persist after incisional and excisional wounding? Plast Reconstr Surg. 2009; 121(2): 487-96. DOI: 10.1097/01. prs.0000299183.88334.37

5. Ernis G. Pengaruh Ekstrak Umbi "Simbagh Utak" (Hydnophytum sp) terhadap Kadar Asam Urat Mus musculus Jantan dan Karakterisasi Hasil Isolasi Menggunakan FTIR [minor thesis]. Bengkulu: University of Bengkulu; 2013.

6. Roslizawaty, Budiman H, Laila H, Herrialfian. The Effect Ethanolic Extract of Ant Plant (Myrmecodia sp.) on Histophatological Changes in the Kidney of Hiperurisemic Male Mice (Mus musculus). J Med Veterinar. 2013; 7(2): 116-120.

7. Prachayasittikul S, Pingaew R, Yamkamon V, Worachartcheewan A, Wanwimolruk S, Ruchirawat S, et al. Chemical Constituents and Antioxidant Activity of Hydnophytum formicarum Jack. Int J Pharmacol. 2013; 8(5): 440-4. DOI: 10.3923/ijp.2012.440.444

8. Wijaya BA, Citraningtyas G, Wehantouw F. Potensi Ekstrak Etanol Tangkai Daun Talas (Colocasia esculenta [L]) Sebagai Alternatif Obat Luka Pada Kulit Kelinci (Oryctolagus cuniculus). Pharmacon. 2014; 3(3): 211-9.

9. de Albuquerque Montenegro $C$, Gonçalves GF, de Oliveira Filho AA, Lira AB, Cassiano TTM, de Lima NTR, et al. In Silico Study and Bioprospection of the Antibacterial and Antioxi-dant Effects of Flavone and Its Hydroxylated Derivatives. Molecules. 2017; 22(6): 869. DOI: $10.3390 /$ molecules22060869

10. Malangngi LP, Sangi MS, Paendong JJE. Penentuan Kandungan Tanin dan Uji Aktivitas An-tioksidan Ekstrak Biji Buah Alpukat (Persea Americana mill). J MIPA. 2012; 1(1): 5-10. DOI: $\underline{10.35799 / j m .1 .1 .2012 .423}$ 
11. Maisetta G, Batoni G, Caboni P, Esin S, Rinaldi AC, Zucca P. Tannin profile, antioxidant properties, and antimicrobial activity of extracts from two Mediterranean species of para-sitic plant Cytinus. BMC Complement Altern Med. 2019; 19: 82. DOI: $10.1186 /$ s12906-019-2487-7

12. Subroto MA, Saputro H. Gempur Penyakit dengan Sarang Semut. Jakarta: Penebar Swadaya; 2006. p. 23-30.

13. Suryajaya W. Induksi ekstrak sarang semut terhadap proliferasi limfosit pada tikus Wistar [minor thesis]. Surabaya: Airlangga University; 2012.

14. Fonseca E, Nesland JM, Hoie J, SobrinhoSimoes M. Pattern of expression of intermediate cytokeratin filaments in the thyroid gland: an immunohistochemical study of simple and stratified epithelial-type cytokeratins. Virchows Archiv. 1997; 430: 23945. DOI: $10.1007 / \mathrm{BF} 01324808$

15. Al-Bayaty FH, Abdulla MA, Abu Hassan MI, Mohd Ali A. Effect of Andrographis pa-niculata leaf extract on wound healing in rats. Natural Product Res. 2012; 26(5): 423-9. DOI: 10.1080/14786419.2010.496114

16. Yuza F, Wahyudi IA, Larnani S. The Effect of Aloe Barbadensis Miller Extract to The Density of Collagen Fibers in The Wound Healing Process after Tooth Extraction of Guinea Pig (Cavia porcellus). Maj Ked Gi Ind. 2014; 21(2): 127-135. DOI: $10.22146 /$ majkedgiind. 8743

17. Yugoshi LI, Sala MA, Brentegani LG, Carvalho TLL. Histometric Study of Socket Healing af-ter Tooth Extraction in Rats Treated with Diclofenac. Braz Dent J. 2002; 13(2): 92-6. DOI: $10.1590 / s 0103-64402002000200003$
18. Ginwala R, Bhavsar R, Chigbu DGI, Jain P, Khan ZK. Potential Role of Flavonoids in Treat-ing Chronic Inflammatory Diseases with a Special Focus on the Anti-Inflammatory Activity of Apigenin. Antioxidants (Basel). 2019; 8(2): 35. DOI: $10.3390 /$ antiox8020035

19. Ardiana T, Kusuma ARP, Firdausy MD. Efektivitas Pemberian Gel Binahong (Anredera cor-difolia) 5\% Terhadap Jumlah Sel Fibroblast Pada Soket Pasca Pencabutan Gigi Marmut (Cavia cobaya). Odonto Dent J. 2015; 2(1): 64-70. DOI: $10.30659 /$ odj.2.1.64-70

20. Zhang J, Jiang Q, Na S, Pan S, Cao Z, Qiu J. Minimal Scar Dissection for Partial Parotidectomy via a Modified Cosmetic Incision and an Advanced Wound Closure Method. J Oral Maxillofac Surg. 2019; 77(6): 1317. e1-1317. e9. DOI: $10.1016 /$ j.joms.2019.02.036

21. Chokotho $L$, van Hasselt $E$. The use of tannins in the local treatment of burn wounds - a pilot study. Malawi Med J. 2005; 17(1): 19-20.

22. Sabirin IPR, Maskoen AM, Hernowo BS. Role of Noni (Morinda citrifolia L.) Leaf Ethanolic Extract Topical Application on Wound Healing Examined from CD34 Immunoexpression and Collagen on Wistar Rats. Maj Ked Bandung. 2013; 45(4): 226-33. DOI: 10.15395/mkb. v45n4.169

23. Trombelli L, Farina R, Marzola A, Bozzi L, Liljenberg $B$, Lindhe J. J Clin Periodontol. 2008; 35(7): 630-9. DOI: $10.1111 / \mathrm{j} .1600$ 051X.2008.01246.X

24. Yulinah E, Sukrasno, Fitri MA. Aktivitas Antidiabetik Ekstrak Etanol Herba Sambiloto (An-drographis paniculata Nees (Acanthaceae)). J Mat Sains. 2001; 6(1): 1320. 